Sādhanā Vol. 29, Part 1, February 2004, pp. 13-26. (O Printed in India

\title{
Tribomechanical micronization and activation of whey protein concentrate and zeolite
}

\author{
Z HERCEG, V LELAS, M BRNČIĆ, B TRIPALO and D JEŽEK \\ Faculty of Food Technology and Biotechnology, University of Zagreb, \\ Pierottijeva 6, 10000 Zagreb, Croatia \\ e-mail: zherceg@pbf.hr
}

MS received 11 December 2002; revised 9 September 2003

\begin{abstract}
Tribomechanics is a part of physics that is concerned with the study of phenomena that appear during milling under dynamic conditions. Tribomechanical micronization and activation (TMA) of whey protein concentrates (WPC) and zeolites (type clinoptilolite) were carried out. Samples of powdered WPC and zeolite were treated with the laboratory TMA equipment. The treatment was carried out at two various rotor speeds: 16,000 and 22,000 r.p.m. at ambient temperature. Analyses of the particle size and distribution as well as the specific area and scanning electron microscopy were carried out on the powdered WPC and zeolite, before and after the TMA treatment. Suspensions of the WPC and zeolite were treated with ultrasound, just before determining the particle size distribution, at $50 \mathrm{kHz}$. The results showed that tribomechanical treatment causes significant decrease in particle size, change in particle size distribution and increase in specific area of WPC and zeolite. These changes of the treated materials depend on the type of the material, the level of inserting particles, the planned angle of the impact, internal rubbing and the planned number of impacts. The effects found became stronger as the rotor speed of the TMA equipment increased (16,000 to 22,000 rpm). Ultrasonic treatment of suspension of tribomechanically treated WPC resulted infurther breakdown of partly damaged protein globules as proved with the statistic analyses. No further changes in their granulometric composition were caused by ultrasonic treatment of a suspension of tribomechanically treated zeolite.
\end{abstract}

Keywords. Tribomechanical micronization; whey protein concentrate; zeolite; ultrasonic treatment.

\section{Introduction}

Tribomechanics is a branch of physics that is concerned with the study of phenomenon that appear during milling under dynamic conditions. This process has been known for about 60 years, when the first equipment for tribomechanical milling was constructed in Russia. So far investigations have been focused only on building and ore materials.

In the year 1998, the process of tribomechanical micronization and activation (TMA) as well as the appropriate equipment was patented in Geneva (Lelas 1998). 
This recently designed device for dynamically fine milling and micronization is a complex unit in which different materials, both organic (why protein concentrates, WPC) and inorganic (zeolites) are subjected to fine milling and micronization under dynamic conditions.

Investigations of the effect of tribomechanically activated zeolites on biological systems have been carried out in several countries. First results have shown that TMA zeolites, owing to their changed physico-chemical properties, can have very positive effects on various pathological conditions of organisms (Cefali et al 1995; Colic \& Pavelić 2000; Pavelić et al 2000).

With regard to the results obtained with mineral substances, we feel that the procedure of tribomechanical activation can be also applied for the treatment of some organic materials.

Physical and structural properties of proteins sometimes can be altered by mechanical means. High pressure and ultrasonic vibration cause denaturation which has a significant influence on the physical and structural characteristics of proteins. Previous investigations have shown that ultrasound, besides breaking the agglomerates that may form, may also significantly change the structural characteristics of whey proteins (Bryant \& McClements 1999; Apenten et al 2000). Many studies have shown that high pressures (up to $800 \mathrm{MPa}$ ) can modify protein structure and reactivity. The $\beta$-lactoglobulin, the main whey protein component, seems to be more sensitive to high pressure treatment than other food proteins (Galazka et al 1996, 2000; Van Camp et al 1996; Dumay et al 1998; Messens et al 1999). Owing to such effects of high pressure treatments and ultrasonic vibration on the physical and structure properties of proteins, it is to be expected that the process of tribomechanical micronization and activation (TMA) can cause similar changes. Previous investigation with WPC has shown that after TMA treatment, changes occur in the functional, rheological and thermophysical properties of WPC. After TMA treatment, significant improvement of the functional properties of the WPC model system occurs, such as foaming and emulsification, increase in viscosity and decrease in freezing point (Herceg et al 2002; Lelas \& Herceg 2002, Lelas et al 2003).

In this work, whey proteins and zeolite were subjected to TMA treatment. The purpose of this research was to establish the possible influence of this procedure on changes in shape and granulometrical composition of WPC and zeolite (type clinoptilolite), and to determine whether ultrasonic treatment after TMA treatment has an influence on changes in shape and particle size distribution of the investigated materials.

\section{Materials and methods}

In this work the investigations were carried out with powdered WPC, produced by "Meggle" $\mathrm{GmbH}$, Wasserburg, Germany and zeolite (clinoptilolite).

The chemical composition of whey protein concentrate is taken as declared by the manufacturer (table 1).

Zeolites are natural microporous silica minerals, of the composition Al-Na or Al-Ca silicates. For tribomechanic treatment in the patented equipment, crystal zeolite-type clinoptilolite was chosen. The crystal structure is tetrahedron, composed $\mathrm{SiO}_{4}$ and $\mathrm{AlO}_{4}$.

Table 1. Chemical compositions of whey protein concentrate.

\begin{tabular}{lccccc}
\hline Sample & Proteins (\%) & Lactose $(\%)$ & Fat $(\%)$ & Water (\%) & Ash $(\%)$ \\
\hline WPC & 80.0 & 5.0 & 6.0 & 3.0 & 6.0 \\
\hline
\end{tabular}



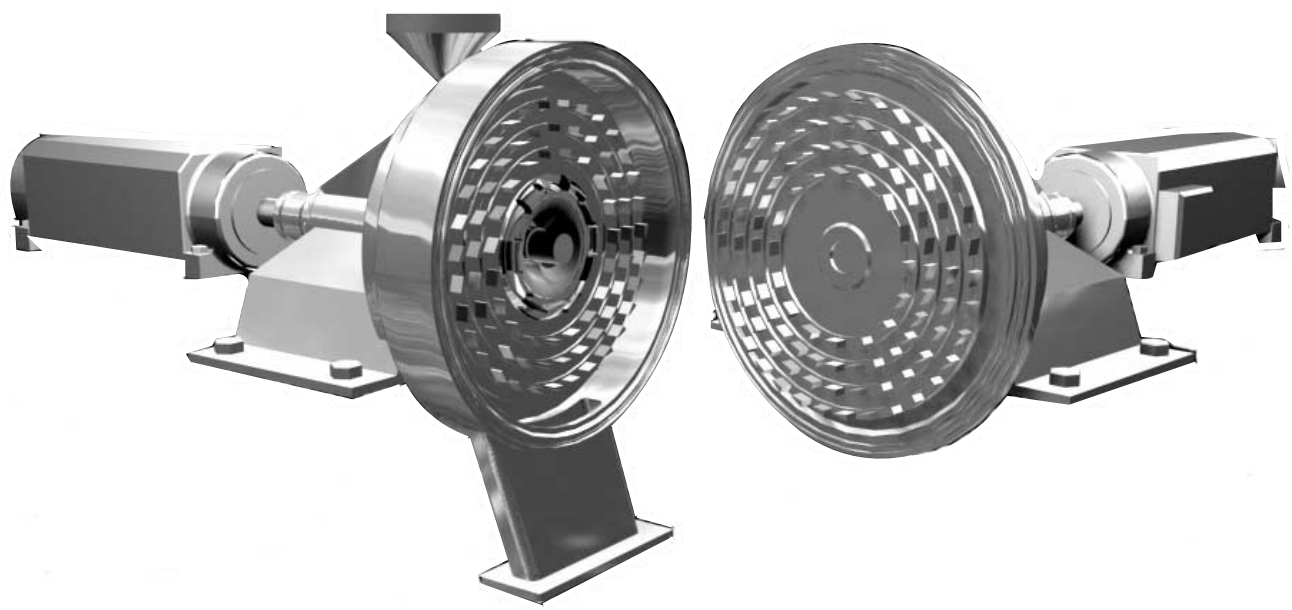

Figure 1. Laboratory equipment for tribomechanical micronization and activation (TMA equipment).

\subsection{Tribomechanical micronization and activation (TMA)}

Samples were treated in the laboratory using the equipment devised for TMA. The treatment was carried out at two rotor speeds: 16,000 and 22,000 r.p.m. and at ambient temperature. The rate of TMA treatment was $5 \mathrm{~kg} / \mathrm{min}$.

TMA equipment is made up of housing and two rotor disks placed against each other. Each disk is supplied with 3 to 7 concentric wreathes with specially constructed hard metal elements (figure 1). The disks rotate in opposite directions at the same angular rate. The starting material enters the equipment through the central part of the rotor system by ventilator air streaming. The particles are accelerated and, because of the repeated change of direction of motion, are in constant collision, which causes friction in short time intervals (less than 0.001 s).

This equipment, patented by Tihomir Lelas (figure 1), was made by "Bauer Maschinenbau", Hamburg, Germany and is now with the firm "Geomin" Villach, Austria.

The input temperature of the material was $21 \cdot 3^{\circ} \mathrm{C}$, and the outgoing temperature was $30 \cdot 6^{\circ} \mathrm{C}$ for WPC and $33.9^{\circ} \mathrm{C}$ for zeolite. This insignificant temperature difference achieved during micronization is, in spite of the high friction and collisions that occur among the particles, the consequence of cooling the housing of the equipment and the very short time required for the material to pass through the equipment. For micronization of $5.0 \mathrm{~kg}$ powdered material only $60 \mathrm{~s}$ was needed.

\subsection{Analytical methods}

Before and after TMA of powdered WPC and zeolite, the following analyses were carried out: particle size and distribution, specific surface area, scanning electron microscopy. Each analysis was done in triplicate and mean values were taken into consideration.

\subsection{Particle size}

The particle size distribution of powdered WPC and zeolite was performed using a Fritsch laser particle sizer, Analysette 22, by measuring the angular dependence of the scattered laser light intensity from a dilute suspension, and indicating the particle size distribution. Particle 
size distribution was calculated by a computer program according to the Fraunhofer model of light scattering, which gives the closest fit between theoretical calculations and experimental measurements (Washington 1992).

A suspension of the materials under study was treated with ultrasound at $50 \mathrm{kHz}$. (1-10 minutes), just before determining a particle size distribution.

MIE-theory was used for specific surface area determination (using Fritsch's computer program). But the mathematical details are too extensive to be discussed usefully here. They are treated in detail by Bohren \& Huffman (1983).

\subsection{Scanning electron microscopy}

Scanning electron microsopy of powdered WPC and zeolite before and after TMA treatment was made after sample preparation technique using an Edwards S-150, sputter-coater unit. Electron micrographs were taken with JOEL-JSM-5800.

\subsection{Statistical analysis}

Data elaboration on particle size distribution before and after TMA and ultrasound treatment in time periods from 0 to 10 minutes is made by comparison of particles smaller than the earlier values, using the method of differences ( $t$-test). Testing was performed for 5 values $(1 \cdot 26,2 \cdot 23,7 \cdot 78,14 \cdot 08$ and $25 \cdot 17 \mu \mathrm{m})$.

\section{Discussion}

Use of solutions in the equipment for fine dynamic milling and micronization enables significant saving of energy, as the losses of energy during milling are smaller than with the classic methods where the significant amount of energy is lost as friction during rubbing. Classical milling methods take much more time, and very fine results cannot be achieved, and hence this new method is very acceptable, because of significant energy savings. In this new by devised equipment, striking hammers and ventilation paddles placed on rotating discs produce turbulent movement of materials that are treated. During milling, particles collide and rub each other in short time intervals (less than 0.001 s) and significant amount of energy is saved. During TMA treatment, because the materials stay a short time in the equipment for tribomechanical activity there is a small rise in temperature of the material. The input temperature of the material was $21 \cdot 3^{\circ} \mathrm{C}$, while the outgoing temperature was $30 \cdot 6^{\circ} \mathrm{C}$ for WPC and $33.9^{\circ} \mathrm{C}$ for zeolite (table 2, figures 2 and 3 ).

With the described procedure of milling and micronization, owing to the intensive mechanical pressure, there is a change of granulometric composition of the material. This depends on the size of the starting materials, the level of fastening particles, the planned angle of crash and rubbing, and the planned number of crashes (table 2, figures 2-7). It is noticed that the number of turnings of the rotating discs (r.p.m.) significantly influences the granulometric composition of zeolite and WPC. With rising rotations with rotating discs from 16,000 to 22,000 r.p.m. the size of particles became smaller by $50 \%$, independent of whether WPC or zeolite is milled.

The procedure of TMA treatment does not create changes in the chemical composition of natural mineral zeolite, but the process of TMA treatment in significant proportion changes the physical characteristics of the treated material (Bhushan 2000; Lelas \& Herceg 2002). The more significant changes are in the size of particles, the active surface (table 2, figures 2-7) 
Table 2. Particle size analysis and specific surface area of powdered WPC and zeolite before and after TMA treatment.

\begin{tabular}{lccccr}
\hline & & \multicolumn{3}{c}{ Particle size $(\mu \mathrm{m})$} \\
\cline { 5 - 6 } Sample & Treatment & $\begin{array}{c}\text { Surface area } \\
\left(\mathrm{m}^{2} / \mathrm{g}\right)\end{array}$ & $\begin{array}{c}10 \% \\
\text { under* }\end{array}$ & $\begin{array}{c}50 \% \\
\text { under** }\end{array}$ & $\begin{array}{c}90 \% \\
\text { under*** }\end{array}$ \\
\hline \multirow{3}{*}{ WPC } & Untreated & 0.5836 & 38.41 & 59.73 & 166.24 \\
& $16,000 \mathrm{rpm}$ & 1.2534 & 3.39 & 17.93 & 68.71 \\
\multirow{2}{*}{ Zeolite } & $22,000 \mathrm{rpm}$ & 1.3770 & 1.59 & 12.93 & 34.15 \\
& Untreated & 0.6482 & 14.27 & 43.63 & 333.65 \\
& $16,000 \mathrm{rpm}$ & 1.7543 & 1.99 & 9.11 & 44.12 \\
& $22,000 \mathrm{rpm}$ & 2.3638 & 1.48 & 6.34 & 31.15 \\
\hline
\end{tabular}

Using Fraunhofer theories it is established that ${ }^{*} 10 \%,{ }^{* *} 50 \%,{ }^{* * *} 90 \%$ of particles have smaller diameters than quoted

and electrostatic charge and capacity of the ion (Herceg 2000). As the result of the described interaction in zeolite, the crystals of the material at the surface get destroyed or damaged, and therefore partially change from crystal to amorphous form. This results in changes in physical and energetic characteristics of the material (Bhushan 2000; Boranić 2000).

WPC according to their structure is a compact globular protein with relatively equal distribution of chains of polar (hydrophobic), non-polar (neutral) and uncharged and charged residues of aminoacid/acid and base). Intramolecular wrinkled structure of these proteins is the result of disulfide bonds (S-S) between cysteine residues, which inside the moleculas mainly covered with hydrophobic residues. WPC consists of three main fractions: lactoalbumins (mole masses from 14,000 to 69,000), imunoglobulins (mole masses from 150,000 to $1,000,000)$ proteases and peptons (mole masses from 4,000 to 10,000) (Tratnik 1998). During TMA treatment, the protein globules are mechanically separated, during which it is noticed

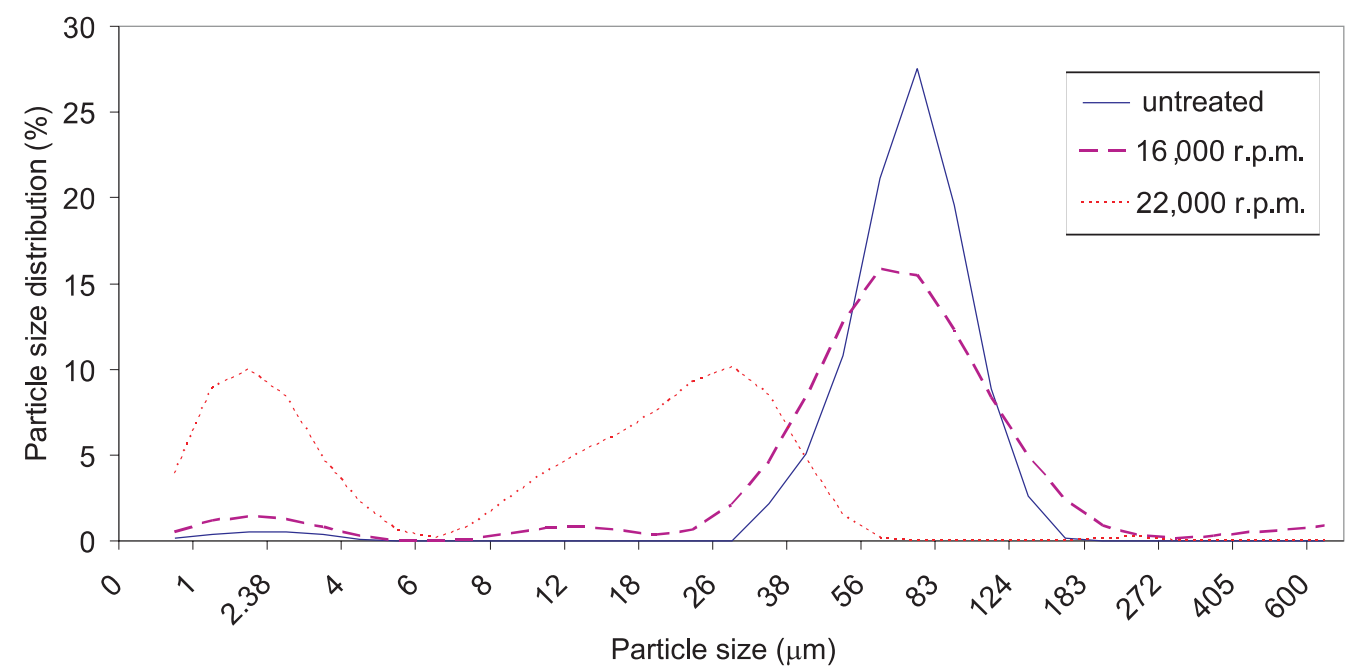

Figure 2. Particle size distribution of powdered WPC before and after tribomechanical treatment. 


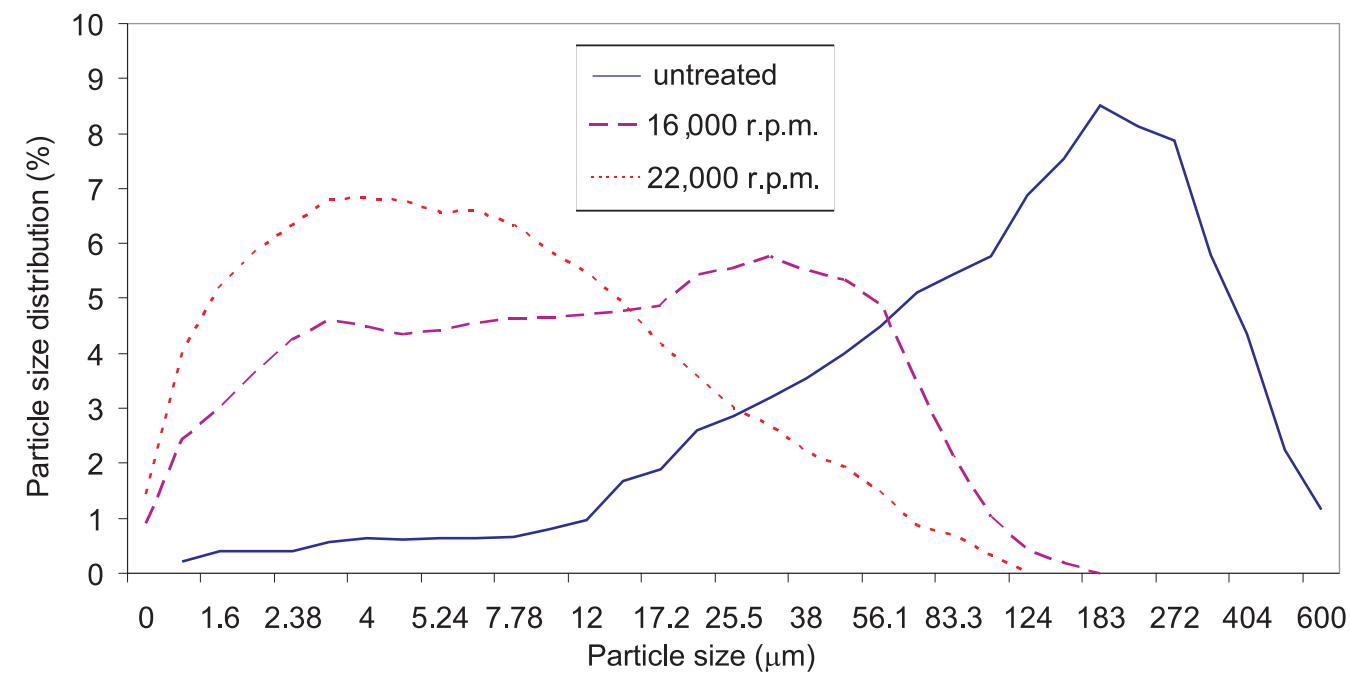

Figure 3. Particle size distribution of zeolite before and after tribomechanical treatment.

that the biggest changes are in the imunoglobulins; this is understandable considering the size of their globules (figures 4 and 5) (Herceg 2000)

During treatment of WPC the protein globulas divide producing the smaller mole mass products as protein fragments, peptides and aminoacids. Due to this the chemical composition of material is changed, as well as its physical, chemical and functional characteristics (Herceg et al 2002; Lelas \& Herceg 2002; Lelas et al 2003). This way of breaking up the material, compared to the standard way, induces significantly higher free energy and higher capacity to enter into other reactions (Herceg 2000).

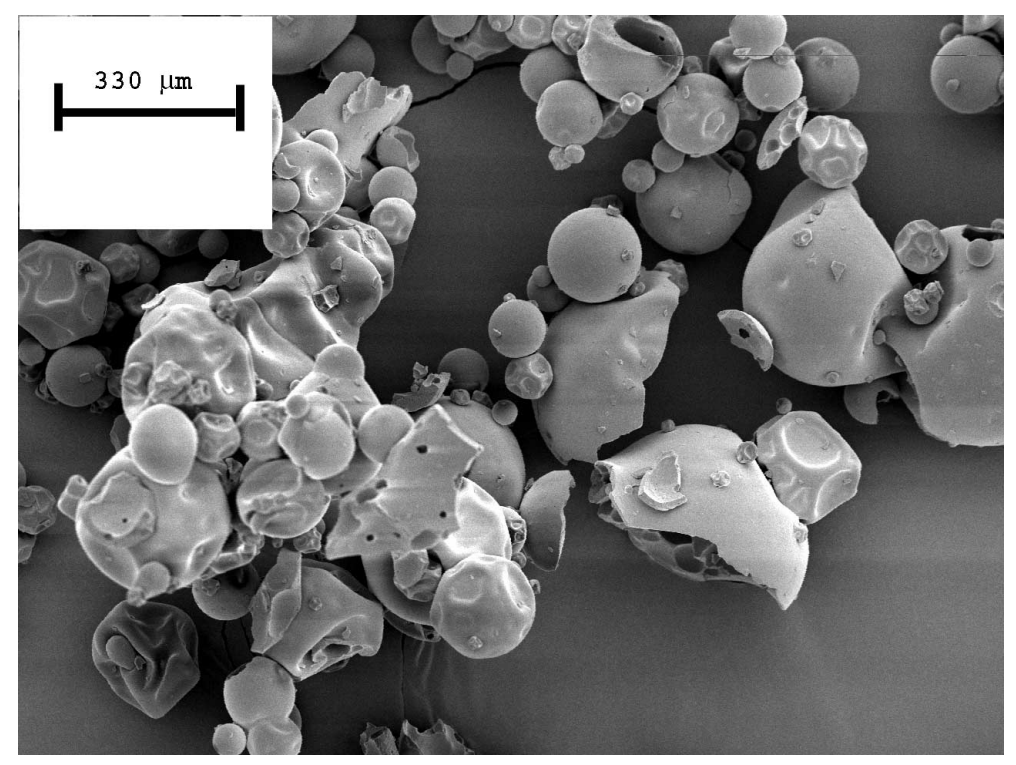

Figure 4. Morphology of untreated protein globules of powdered WPC. 


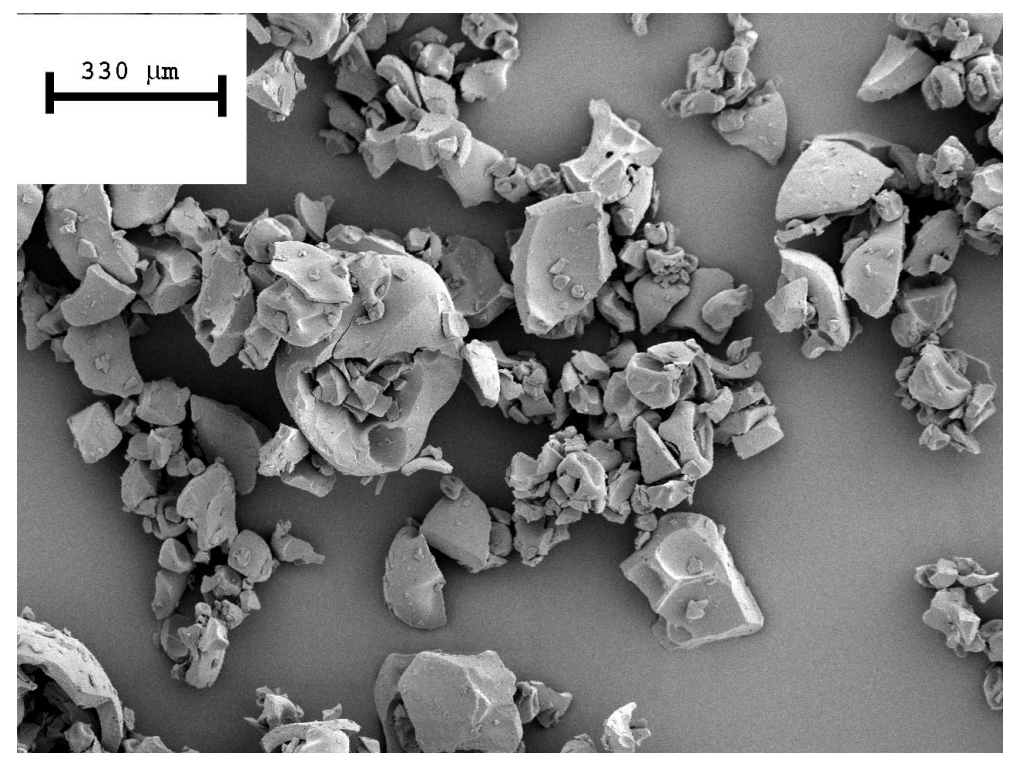

Figure 5. Morphology of tribomechanicaly treated $(22,000 \mathrm{rpm})$ protein globules of powdered WPC.

After the TMA treatment the specimen is treated with ultrasound. The ultrasonic treatment is given in order to check the effect of ultrasound on the partly damaged protein globules or crystals of zeolite after TMA treatment (Apanten et al 2000; Joyner \& Stockenhuber 1999).

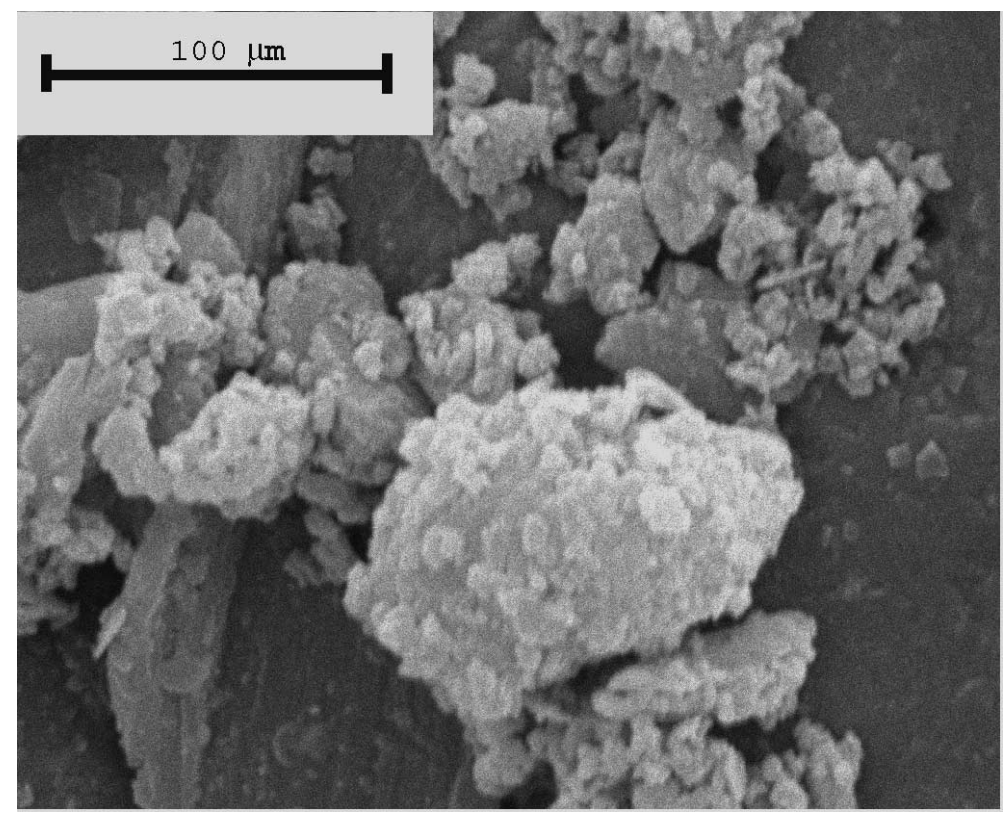

Figure 6. Morphology of untreated zeolite. 


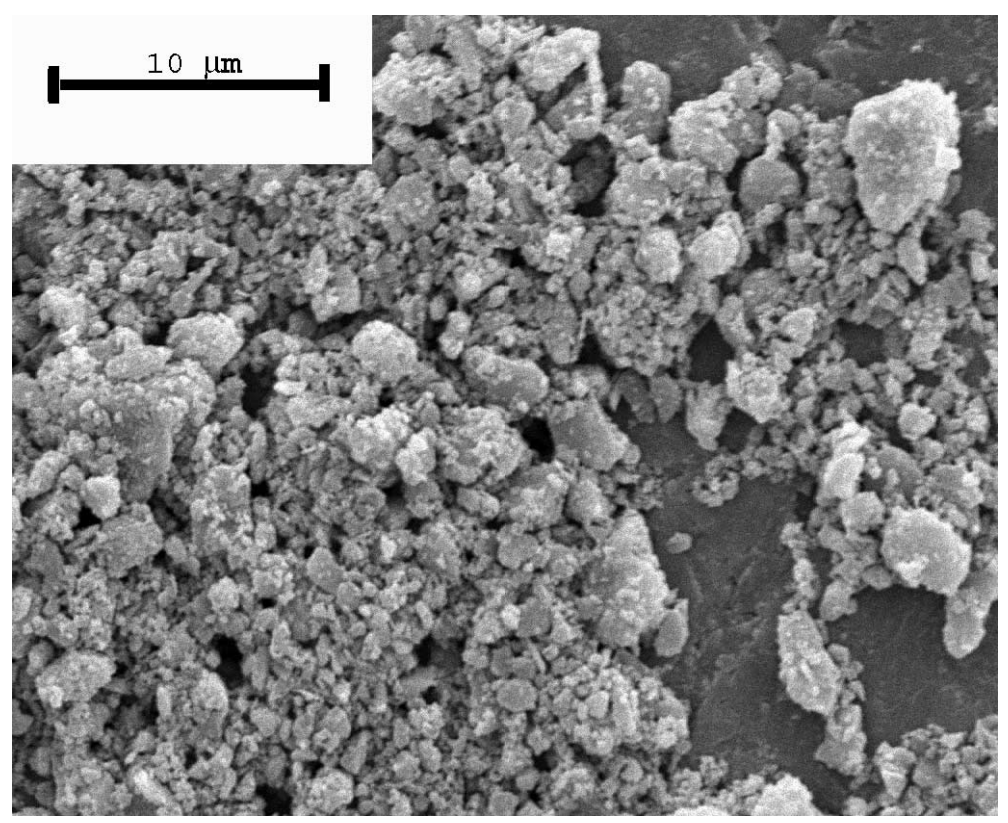

Figure 7. Morphology of tribomechanicaly treated $(22,000 \mathrm{rpm})$ zeolite.

After ultrasonic treatment it is noticable that there is a change in the particle size of the treated materials. The most significant change in particle size of the zeolite and WPC is observed within the first minute with ultrasound treatment, which is understandable regarding the fact that in this case ultrasound breaks up the agllomerated particles (figures 8-11). With

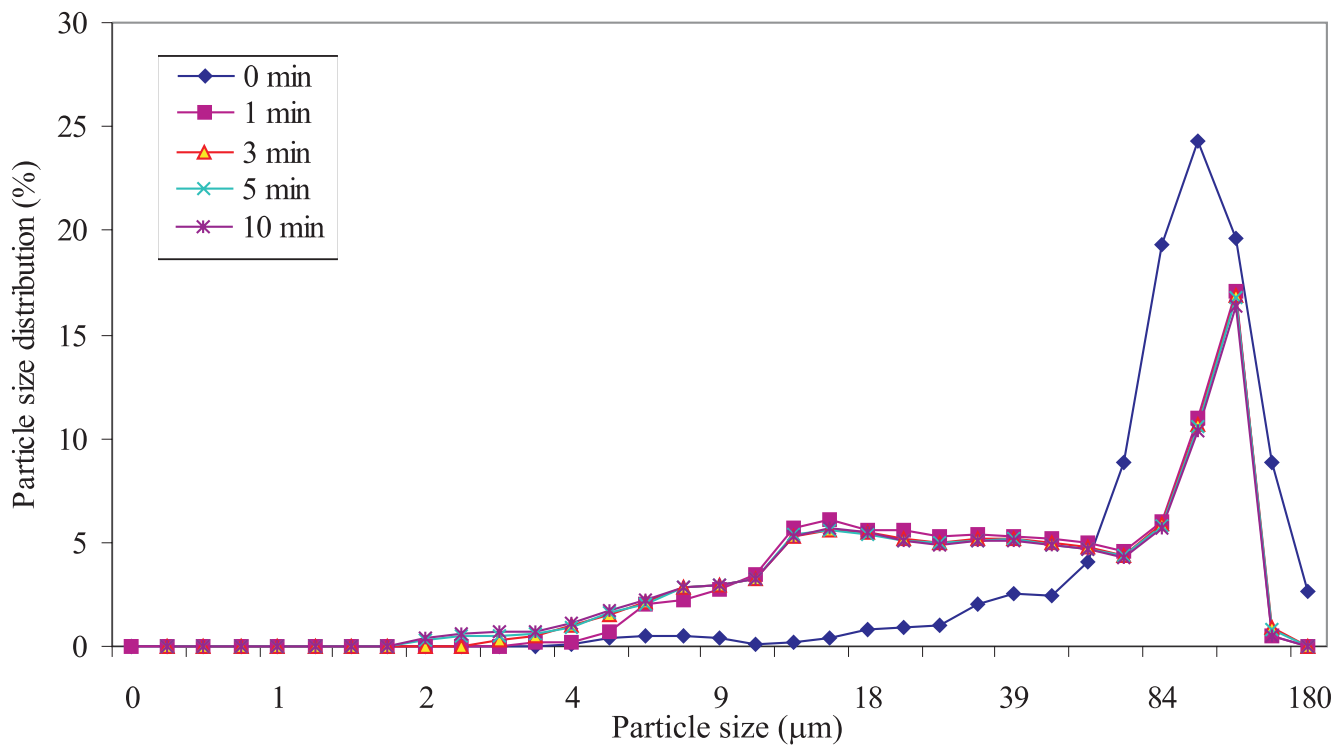

Figure 8. Influence of ultrasound on particle size distribution of WPC before tribomechanical micronization. 


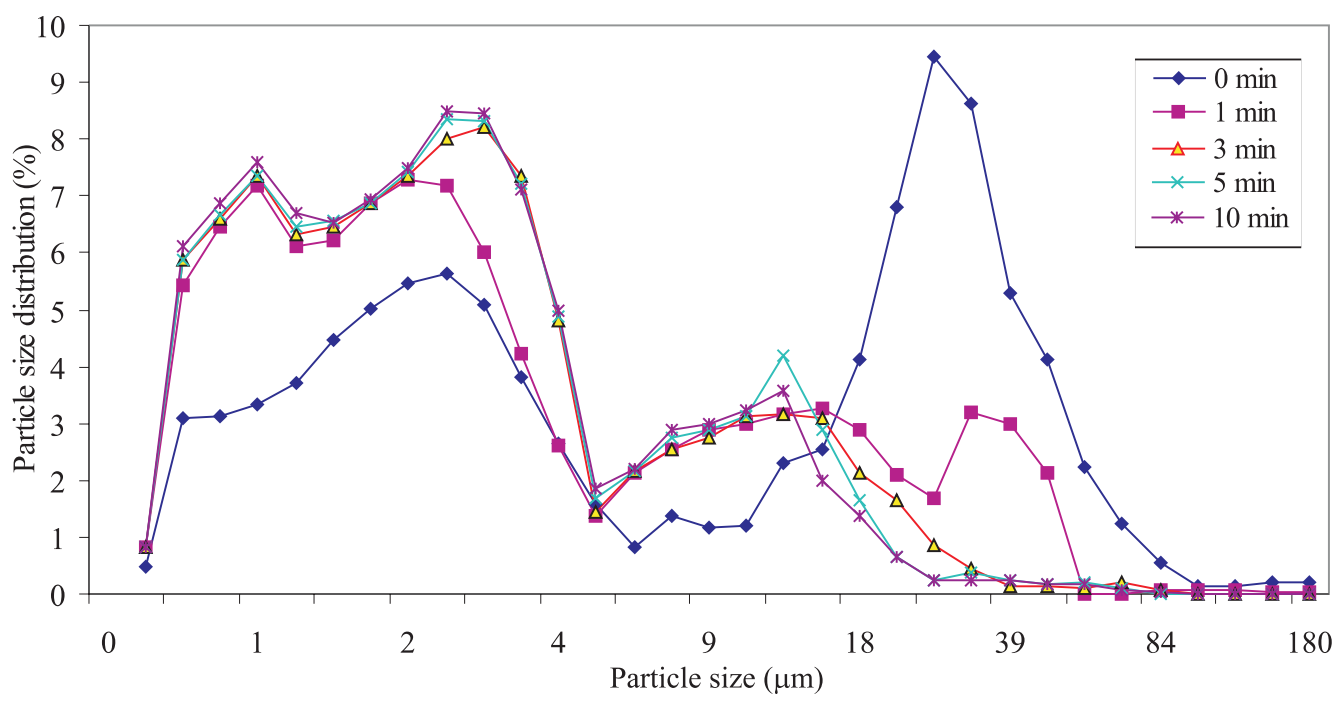

Figure 9. Influence of ultrasound on particle size distribution of WPC after tribomechanical micronization at 22,000 r.p.m.

further ultrasonic treatment however there are no significant differences in WPC and zeolite behaviour. It is characteristic that material that has not been tribomechanically treated after the first minute of ultrasonic treatment does not show any significant change in the size of particles (figures 8 and 10), while after TMA treatment of WPC, it is noticed that with ultrasonic treatment for longer than one minute, particle size keeps getting smaller (figure 9).

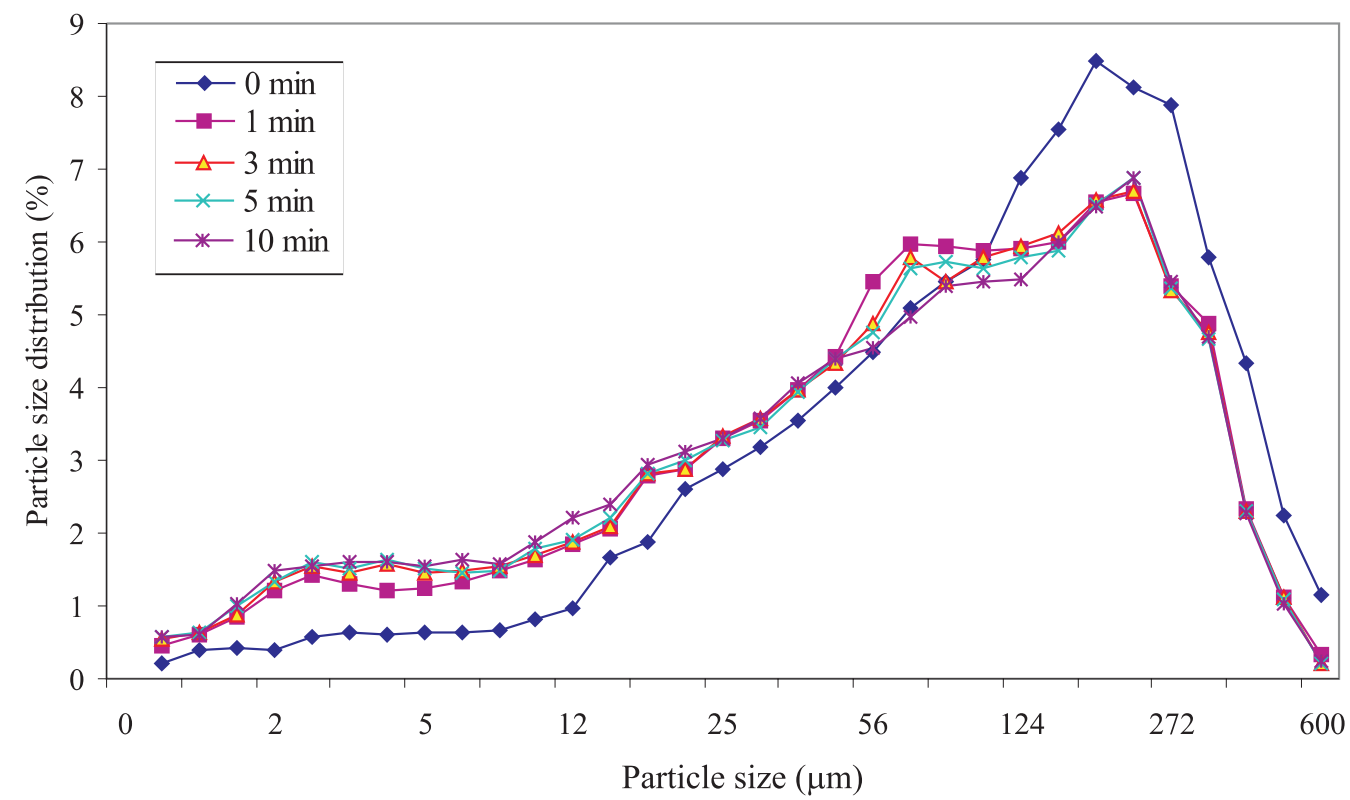

Figure 10. Influence of ultrasound on particle size distribution of zeolite before tribomechanical micronization. 


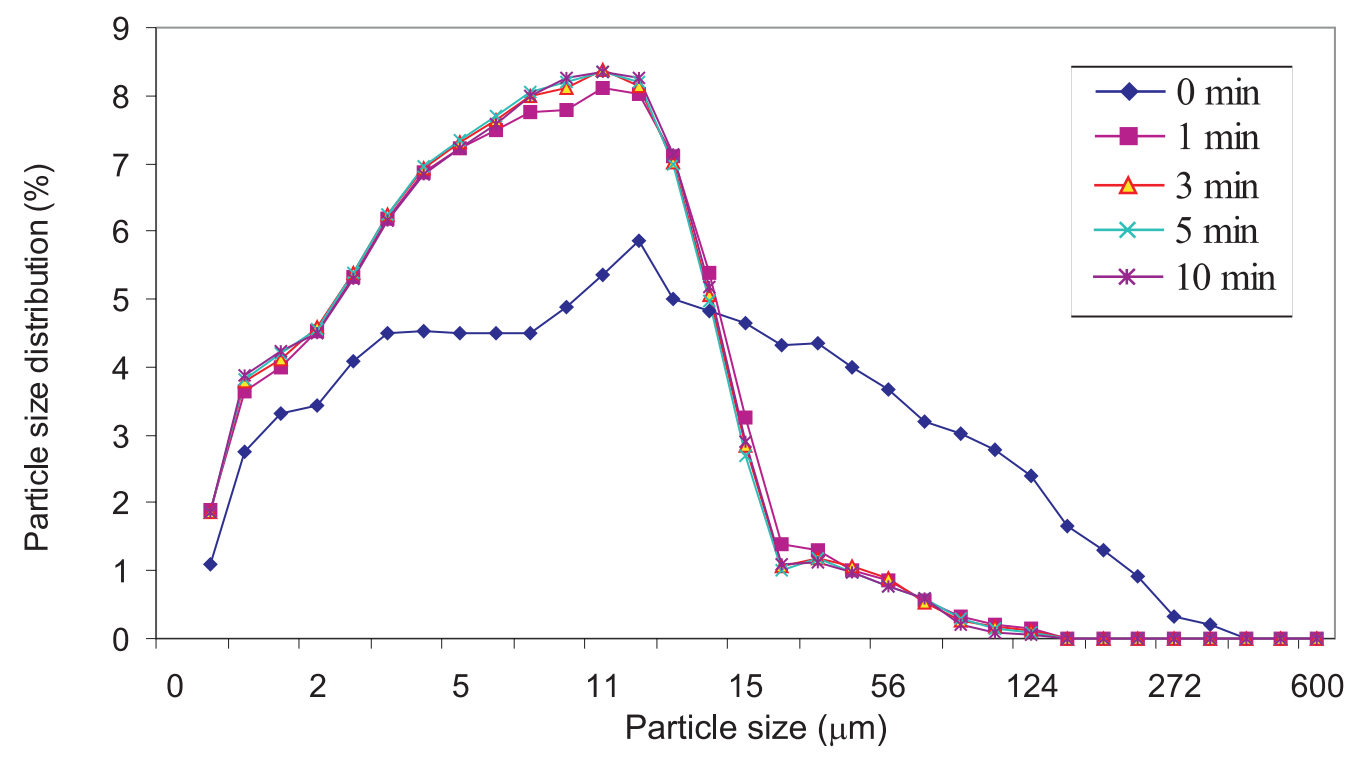

Figure 11. Influence of ultrasound on particle size distribution of zeolite after tribomechanical micronization at 22,000 r.p.m.

So, after agllomerate breaking up, ultrasonic treatment continues with the breaking up of the WPC particles in to smaller and smaller fragments. This influence of ultrasonic treatment on the tribomechanically treated WPC can be explained as the result of TMA treatment that causes breaking up of compact protein globulas in to peptides, protein fragments (figures 2 and 3), and thus the damaged globules are disposed to further breaking up caused by the ultrasound treatment (tables 4 and 6). This assumption is proved by the fact that nontreated WPC does not significantly have further change in the size of particles with further ultrasonic treatment (2-10 min) (tables 3 and 5, figure 8). Unlike for the WPC, zeolite, after TMA treatment and breaking up of agllomerates does not significantly show change in the size of particles (figure 10).

Statistical analysis based on the parametric statistical method of treating the results of granulometric analyses proved unsuitable. Because of a small number of very big particles and a large number of small particles in the statistical analyses, we get inadequate disproportion of the arithmetic mean and standard deviation (with the aritmetic mean 1, the standard deviation is 10). Further on, nonparametric methods based on the differences between median distributions are not applicable in this case, because with all distributions the medians are small, and the differences are only those between medians gained by interpolation.

Therefore, data processing on distribution of particles before and after TMA treatment and ultrasonic treatment in time periods in the range 0 to 10 minutes is done by comparing the proportions of smaller particles with some earlier data, with the method of differences among the proportions. The testing was done for 5 values $(1 \cdot 26,2 \cdot 23,7 \cdot 78,14 \cdot 08$, and $25 \cdot 17 \mu \mathrm{m})$. Since the results are identical, in this work we have shown only the differences between particle proportions smaller than $14.08 \mu \mathrm{m}$. The result is considered statistically significant if the probability of mistakes with rejection of zero hypotheses is smaller than $1 \%$.

The differences among proportions with tribomechanically untreated WPC are statistically significant between the size of particles before the ultrasound treatment and after the first minute of ultrasonic treatment, in the sense that after ultrasonic treatment for one minute, 
Table 3. Ultrasonic influence on particle size distribution and specific surface area of powdered WPC and zeolite before TMA treatment.

\begin{tabular}{|c|c|c|c|c|c|}
\hline \multirow[b]{2}{*}{ Sample } & \multirow{2}{*}{$\begin{array}{l}\text { Treatment } \\
\text { with } \\
\text { ultrasound } \\
\text { (min) }\end{array}$} & \multirow[b]{2}{*}{$\begin{array}{c}\text { Specific } \\
\text { surface area } \\
\left(\mathrm{m}^{2} / \mathrm{g}\right)\end{array}$} & \multicolumn{3}{|c|}{ Particle size $(\mu \mathrm{m})$} \\
\hline & & & $\begin{array}{c}10 \% \\
\text { under* }\end{array}$ & $\begin{array}{c}50 \% \\
\text { under** }\end{array}$ & $\begin{array}{c}90 \% \\
\text { under*** }\end{array}$ \\
\hline \multirow{5}{*}{ WPC } & 0 & 0.5736 & $38 \cdot 41$ & 59.73 & $166 \cdot 24$ \\
\hline & 1 & 0.7754 & 21.64 & 41.11 & 89.23 \\
\hline & 3 & 0.7801 & $20 \cdot 76$ & 40.99 & $71 \cdot 34$ \\
\hline & 5 & 0.7804 & $20 \cdot 75$ & 40.89 & 71.27 \\
\hline & 10 & 0.7806 & $20 \cdot 72$ & $40 \cdot 77$ & $71 \cdot 22$ \\
\hline \multirow{5}{*}{ Zeolite } & 0 & $0 \cdot 6482$ & $14 \cdot 27$ & 143.63 & 333.56 \\
\hline & 1 & 0.7860 & 7.73 & $96 \cdot 11$ & $302 \cdot 11$ \\
\hline & 3 & 0.7950 & 6.87 & 95.06 & $300 \cdot 86$ \\
\hline & 5 & 0.7970 & 6.75 & 95.03 & $300 \cdot 85$ \\
\hline & 10 & 0.7980 & $6 \cdot 68$ & 94.94 & $300 \cdot 83$ \\
\hline
\end{tabular}

Using Fraunhofer theories it is established that ${ }^{*} 10 \%,{ }^{*} 50 \%,{ }^{* * *} 90 \%$ of particles have smaller diameters than quoted

the approximate size of particles gets smaller (the number of particles smaller than $14.08 \mu \mathrm{m}$ increases). With further ultrasonic treatment, the changes of size of the particles is statistically significant (table 5).

Differences among proportions with tribomechanically treated WPC are statistically significant between the size of particles before ultrasonic treatment and after one minute of treatment, and further ultrasound treatment as well. With further ultrasonic treatment the size of particles becomes smaller still, and the difference is statistically significant between one and three minutes, and between three and five minutes (table 6).

Table 4. Ultrasonic influence on particle size distribution and specific surface area of powdered WPC and zeolite before TMA treatment.

\begin{tabular}{lccccc}
\hline & \multirow{2}{*}{$\begin{array}{c}\text { Treatment } \\
\text { with }\end{array}$} & Specific & \multicolumn{3}{c}{ Particle size $(\mu \mathrm{m})$} \\
\cline { 4 - 6 } $\begin{array}{c}\text { ultrasound } \\
(\text { min })\end{array}$ & $\begin{array}{c}\text { surface area } \\
\left(\mathrm{m}^{2} / \mathrm{g}\right)\end{array}$ & $\begin{array}{c}10 \% \\
\text { under* }\end{array}$ & $\begin{array}{c}50 \% \\
\text { under** }\end{array}$ & $\begin{array}{c}90 \% \\
\text { under*** }\end{array}$ \\
\hline \multirow{4}{*}{ WPC } & 0 & 1.3870 & 1.59 & 12.93 & 34.15 \\
& 1 & 2.6643 & 0.74 & 3.27 & 30.01 \\
& 3 & 3.8361 & 0.73 & 2.52 & 18.67 \\
& 5 & 4.7889 & 0.70 & 1.44 & 10.67 \\
Zeolite & 10 & 5.3332 & 0.66 & 1.36 & 9.02 \\
& 0 & 2.3738 & 1.48 & 6.34 & 31.15 \\
& 1 & 2.7159 & 1.39 & 4.14 & 25.43 \\
& 3 & 2.7178 & 1.38 & 4.11 & 25.39 \\
& 5 & 2.7181 & 1.38 & 4.09 & 25.39 \\
& 10 & 2.7182 & 1.38 & 4.03 & 25.38 \\
\hline
\end{tabular}

Using Fraunhofer theories it is established that ${ }^{*} 10 \%,{ }^{* *} 50 \%,{ }^{* * *} 90 \%$ of particles have smaller diameters than quoted 
Table 5. Proportion of particles of tribomechanically untreated WPC smaller than bordering value $(14.08 \mu \mathrm{m})$ treated by ultrasound for $0,1,3,5$ and 10 minutes and $Z$-values difference among proportions.

\begin{tabular}{lcccrrr}
\hline & Time $(\min ) \rightarrow$ & 0 & 1 & 3 & 5 & 10 \\
\cline { 2 - 7 } $\begin{array}{l}\text { Time } \\
(\mathrm{min})\end{array}$ & $\begin{array}{c}\text { Proportion of } \\
\text { particles }(\mu \mathrm{m})\end{array}$ & 0.07 & 0.53 & 0.54 & 0.54 & 0.54 \\
\hline 0 & 0.07 & 0.00 & $* 16.26$ & $* 17.43$ & $* 17.71$ & $* 18.24$ \\
1 & 0.53 & $* 16.26$ & 0.00 & 1.39 & 1.87 & 2.44 \\
3 & 0.54 & $* 17.43$ & 1.39 & 0.00 & 0.56 & 0.98 \\
5 & 0.54 & $* 17.71$ & 1.87 & 0.56 & 0.00 & 0.35 \\
10 & 0.54 & $* 18.24$ & 2.44 & 0.98 & 0.35 & 0.00 \\
\hline
\end{tabular}

${ }^{*} Z$ values are larger than 2.56 and therefore statistically significant at the level $p<0.01$

Table 6. Proportion of particles of tribomechanically treated WPC smaller than bordering value $(14.08 \mu \mathrm{m})$ treated by ultrasound for $0,1,3,5$ and 10 minutes and $Z$-value difference among proportions.

\begin{tabular}{|c|c|c|c|c|c|c|}
\hline & Time $(\min ) \rightarrow$ & 0 & 1 & 3 & 5 & 10 \\
\hline $\begin{array}{l}\text { Time } \\
(\min )\end{array}$ & $\begin{array}{l}\text { Proportion of } \\
\text { particles }(\mu \mathrm{m})\end{array}$ & 0.53 & 0.74 & $0 \cdot 82$ & 0.91 & 0.94 \\
\hline 0 & 0.53 & 0.00 & $8.58^{*}$ & $12 \cdot 10^{*}$ & $15 \cdot 03^{*}$ & $15 \cdot 81^{*}$ \\
\hline 1 & 0.74 & $8.58^{*}$ & 0.00 & $3.52 *$ & $6.45^{*}$ & $7 \cdot 23^{*}$ \\
\hline 3 & 0.82 & $12 \cdot 10^{*}$ & $3.52^{*}$ & 0.00 & $2.93^{*}$ & $3.71 *$ \\
\hline 5 & 0.91 & $15.03^{*}$ & $6.45^{*}$ & $2.93^{*}$ & 0.00 & 0.77 \\
\hline 10 & 0.94 & $15 \cdot 81^{*}$ & $7.23^{*}$ & $3 \cdot 71^{*}$ & 0.77 & 0.00 \\
\hline
\end{tabular}

${ }^{*} Z$ values are greater than 2.56 and therefore statistically significant at the level $p<0.01$

Table 7. Proportion of particles of tribomechanically untreated zeolite smaller than bordering value $(14.08 \mu \mathrm{m})$ treated by ultrasound for $0,1,3,5$ and 10 minutes and $Z$-value difference among proportions.

\begin{tabular}{|c|c|c|c|c|c|c|}
\hline & Time $(\min ) \rightarrow$ & 0 & 1 & 3 & 5 & 10 \\
\hline $\begin{array}{l}\text { Time } \\
(\mathrm{min})\end{array}$ & $\begin{array}{l}\text { Proportion of } \\
\text { particles }(\mu \mathrm{m})\end{array}$ & $0 \cdot 10$ & $0 \cdot 21$ & $0 \cdot 21$ & 0.21 & $0 \cdot 21$ \\
\hline 0 & $0 \cdot 10$ & 0.00 & $6 \cdot 29^{*}$ & $6 \cdot 38^{*}$ & $6.40^{*}$ & $6.45^{*}$ \\
\hline 1 & 0.21 & $6.29^{*}$ & 0.00 & 0.09 & 0.11 & $0 \cdot 16$ \\
\hline 3 & $0 \cdot 21$ & $6 \cdot 38^{*}$ & 0.09 & 0.00 & 0.05 & 0.07 \\
\hline 5 & $0 \cdot 21$ & $6.40^{*}$ & $0 \cdot 11$ & 0.05 & 0.00 & 0.06 \\
\hline 10 & 0.21 & $6.45^{*}$ & $0 \cdot 16$ & 0.07 & 0.06 & 0.00 \\
\hline
\end{tabular}

${ }^{*} Z$ values are greater than 2.56 and therefore statistically significant at the level $p<0.01$ 
Table 8. Proportion of particles of tribomechanically treated zeolite smaller than bordering value $(14.08 \mu \mathrm{m})$ treated by ultrasound for $0,1,3,5$ and 10 minutes and $Z$-value difference among proportions.

\begin{tabular}{lcccccc}
\hline & Time $(\min ) \rightarrow$ & 0 & 1 & 3 & 5 & 10 \\
\cline { 2 - 7 } $\begin{array}{l}\text { Time } \\
(\mathrm{min})\end{array}$ & $\begin{array}{c}\text { Proportion of } \\
\text { particles }(\mu \mathrm{m})\end{array}$ & 0.57 & 0.63 & 0.63 & 0.63 & 0.63 \\
\hline 0 & 0.57 & 0.00 & $4 \cdot 84^{*}$ & $6.00^{*}$ & $6.00^{*}$ & $5.77^{*}$ \\
1 & 0.63 & $4.84^{*}$ & 0.00 & 1.15 & $1 \cdot 16$ & 0.93 \\
3 & 0.63 & $6.00^{*}$ & 1.15 & 0.00 & 0.00 & $0 \cdot 23$ \\
5 & 0.63 & $6.00^{*}$ & 1.16 & 0.00 & 0.00 & 0.23 \\
& 0.63 & $5 \cdot 77^{*}$ & 0.93 & 0.23 & 0.23 & 0.00 \\
\hline
\end{tabular}

${ }^{*} Z$ values are greater than 2.56 and therefore statistically significant on the level $p<0.01$

Differences among proportions of tribomechanicaly untreated and treated zeolite are statistically significant between the particles before the ultrasonic treatment and after one minute of ultrasonic treatment, and in the sense that after the ultrasonic treatment for one minute, the approximate size of particle gets smaller (the number of particles smaller than $14.08 \mu \mathrm{m}$ ). With further treatment with ultrasound, the change in size of particles is not statistically significant (tables 7 and 8).

\section{Conclusion}

As a consequence of intensive mechanical strain in the course of tribomechanical treatment, changes in granulometrical composition of WPC and zeolite occur. Changes of the granulometric composition of the treated materials depend on the type of the material, the level of inserting particles, the angle of the collision, internal friction and the planned number of collisions. On increasing the number of rotating discs in the equipment for fine dynamical milling and micronization from 16,000 to 22,000 r.p.m., the size of particles reduced by $50 \%$. During the TMA treatment, the crystals of zeolite on the surface get destroyed or damaged, and the globules of WPC break up. As a result, products of smaller molar mass are obtained - protein fragments and peptides. Ultrasonic treatment of tribomechanically treated WPC further destroys the partly damaged protein globules, as statistical analysis proves. On ultrasonic treatment of tribomechanically treated zeolite, no further changes in their granulometric composition are caused.

\section{References}

Apenten R K O, Buttner B, Mignot B, Pascal D, Povey M J W 2000 Determination of the adiabatic compressibility of bovine serum albumen in concentrated solution by a new ultrasonic method. Food Hydrocolloids 14: 83-91

Bhushan B 2000 Nanoscale tribophysics and tribomechanics. Proc. 12th Int. Conf. on Wear of Materials (Atlanta, GA: Soc. Tribol. Lubric. Eng.) pp 25-29

Bohren C F, Huffman D R 1983 Absorption and sccatering of light by small particles (New York: Wiley) pp 89-91

Boranić M 2000 What a physician should know about zeolites. Liječnički Vjesnik 122: 292-298 
Bryant C M, McClements D J 1999 Ultrasonic spectroscopy study of relaxation and scattering in whey protein solutions. J. Sci. Food Agric. 79: 1754-1760

Cefali E A, Nolan J C, McConnell W R, Walters D L 1995 Pharmacokinetic study of zeolite A, sodium aluminosilicate, magnesium silicate and aluminum hydroxide in dogs. Pharmaceut. Res. 12: $270-274$

Colic M, Pavelić K 2000 Molecular mechanisms of aticancer activity of natural dietetic products. $J$. Mol. Med. 78: 333-336

Dumay E M, Kalichevsky M T, Cheftel J C 1998 Pressure and heat-induced gelation of mixed $\beta$-lactoglobulin/polysaccharide solutions: scanning electron microscopy of gels. Lebensm. Wiss. Technol. 31: 10-19

Galazka V B, Dickinson E, Ledward D A 1996 Effect of high pressure on the emulsyfing behavior of beta-lactoglobulin. Food Hydrocolloids 10: 213-219

Galazka V B, Dickinson E, Ledward D A 2000 Influence of high pressure processing on protein solutions and emulsion. Curr. Opinion Colloid Interface Sci. 5: 182-187

Herceg Z 2000 Influence of tribomechanical micronization of physical properties of whey proteins. $\mathrm{Ph} \mathrm{D}$ thesis, Faculty of Food Technology and Biotechnology, Zagreb, pp 134-146

Herceg Z, Hegedušić V, Rimac S 2000 Influence of hydrocolloid addition on the rheological properties of whey proteins model solutions. Proc. 2nd Int. Symp. on Food Rheology and Structure. Zurich, pp 378-379

Herceg Z, Lelas V, Škreblin M 2002 Influence of tribomechanical micronization on the rheological properties of whey proteins. Food Technol. Biotechnol. 40: 145-156

Joyner R, Stockenhuber M 1999 Preparation, characterization and performance of Fe-ZSM-5 catalysts. J. Phys. Chem. 103: 5963-5976

Lelas T 1998 Vorrichtung zum Mikronisieren von Materialien und neuartige Verwendungsmoglichkeiten derartig mikronisierter Materialien. Patent: PCT/1B 99/00757, Geneva

Lelas V, Herceg Z 2002 Influence of tribomechanical treatment on the phase transition temperatures of whey proteins model systems. Proc. Int. Conf. on Innovation in Food Processing Technology and Engineering, Bangkok, pp 24-34

Lelas V, Herceg Z, Rimac-Brnčič S 2003 Physical properties of tribomechanicaly micronized whey proteins. Proc. New Functional Ingredients and Foods, Copenhagen, pp 58-59

Messens W, Dewttinck K, Van Camp J, Huyghebeart A 1999 High pressure treatment of dairy products. Agric. Biol. Environ. Sci. 31: 115-121

Pavelić K et al 2000 Natural zeolite clinoptilolite: New adjuvant in anticancer therapy. J. Mol. Med. 78: 656-661

Tratnik L 1998 Milk technology, biochemistry and microbiology (Zagreb: Croatian Milk Soc.) pp 345380

Van Camp J, Feys G, Huyghebaert A 1996 Lebensm. Wiss. Technol. 29: 49-57

Washington C 1992 Particle size analysis in pharmaceutics and other industries. Department of Pharmaceutical Science, University of Nottingham, pp 107-115 